PRELIMINARY COMMUNICATIONS

\section{Triglyceride Storage Disease: A Disorder of Lipolysis in Adipose Tissue in Two Patients}

\author{
C. GILBERT, D. J. GALTON, J. KAYE
}

British Medical fournal, 1973, 1, 25-27

\section{Summary}

An obese patient was studied whose adipose tissue showed a significant reduction in release of glycerol $(P<0.05)$ when stimulated by isoprenaline despite normal rises in tissue levels of cyclic-AMP. However, lipolysis was stimulated by a fast of 14 days as judged by weight loss and a rise in plasma fatty acids from 0.4 to $1.2 \mathrm{mM}$. The defect in this patient may be familial since her obese daughter also showed diminished release of glycerol from adipose tissue on three occasions when stimulated by isoprenaline, despite normal rises in levels of cyclic-AMP.

\section{Introduction}

Many attempts have been made to identify a metabolic defect on the pathways of lipolysis in adipose tissue of obese patients to account for the increased accumulation of triglyceride in this tissue. Orth and Williams (1960) studied the effect of adrenaline on the rise in plasma free fatty acids in 10 obese females but found no differences from lean controls. Glennon et al. (1964) found similar rises in plasma fatty acids and glycerol after injection of noradrenaline in lean and obese subjects. Likewise, adipose tissue from lean and obese patients incubated in vitro responded in a similar manner to stimulation by catecholamines, the release of fatty acids and glycerol into the medium being quantitatively very similar in both groups (Bjorntorp and Hood, 1966; Galton and Bray, 1966).

It therefore seems unlikely that an enzymatic defect on the mobilization pathways of triglyceride is contributing to the excess deposition of fat in most cases of obesity. Over the past eight years we have periodically tested the lipolytic response of adipose tissue from obese patients; and we now report our first obese patients (a mother and daughter) who showed an impaired release of glycerol from adipose tissue when stimulated by isoprenaline, despite normal rises in tissue levels of cyclicAMP.

\section{Case Reports}

The mother was a 60 -year-old Caucasian, height $150 \mathrm{~cm}$, who had been persistently overweight. When she first attended hospital in 1958 she weighed $73 \mathrm{~kg}$ ( $28 \%$ over her ideal body weight) and never fell below $15 \%$ over her ideal body weight during 14 years of dietary supervision at hospital. In 1960 she developed xanthomatosis over her palms, elbows, and knees, and the blood pressure at this time was $150 / 105 \mathrm{~mm} \mathrm{Hg}$. Seven years later she weighed $79 \mathrm{~kg}$ and had developed severe dyspnoea on exercise, with angina. The B.P. was now

Diabetes Research Laboratory, St. Bartholomew's Hospital, London E.C.1

C. GILBERT, B.sC., Research Assistant

D. J. GALTON, M.D., M.R.C.P., Consultant Physician

J. KAYE, M.sC., Research Assistant
240/140 $\mathrm{mm} \mathrm{Hg}$, she showed hypertensive retinopathy grade I, and her heart was enlarged, but an E.C.G. showed a normal tracing. She was admitted to hospital in 1969,1971 , and 1972 for stabilization of blood pressure, during which time she developed left ventricular hypertrophy, an ejection systolic murmur over the aortic area, and ischaemic changes on her E.C.G. Additionally, she complained of intermittent claudication and lost her pedal pulses. In her family history, the mother died of a coronary thrombosis at 84 years, the father died of pulmonary tuberculosis at 60 years, she had five sisters who were not available for investigation; and she had an obese daughter.

Laboratory examination showed a serum cholesterol of 390-470 $\mathrm{mg} / 100 \mathrm{ml}$, plasma triglycerides $330-426 \mathrm{mg} / 100 \mathrm{ml}$, plasma fatty acids $0.4 \mathrm{mM}$, and a lipo-protein electrophoretic pattern of type IIb. The glucose tolerance test was normal on three occasions. Protein bound iodine was $5 \cdot 6-8 \cdot 3 \mu \mathrm{g} / 100 \mathrm{ml}$ and $\mathrm{T}-3$ resin uptake was normal. The plasma cortisol (9.00 a.m.) was $10.5 \mu \mathrm{g} / 100 \mathrm{ml}$, electrolytes and urea were normal. She was treated intermittently for hypertension from 1969 onwards with bethanidine or methyldopa and Navidrex-K, but she was unreliable in taking drugs and her blood pressure remained raised (about 240/130 $\mathrm{mm} \mathrm{Hg}$ ).

The daughter, aged 29 years, height $136 \mathrm{~cm}$, and weight $79 \mathrm{~kg}$ ( $35 \%$ over ideal body weight), had no previous medical history except for obesity. Relevant laboratory results were cholesterol $225 \mathrm{mg} / 100 \mathrm{ml}$, triglycerides $350-400 \mathrm{mg} / 100 \mathrm{ml}$, fatty acids $0.61 \mathrm{mM}$, and a lipoprotein strip indicating a type IV pattern.

\section{Materials and Methods}

Source of Adipose Tissue.-Biopsies were taken from the mother (D.D.) on six occasions from the anterior abdominal wall under a variety of different conditions (fed, fasting, on hypotensive therapy, off all therapy, as an inpatient, and as an outpatient) and the results have been meaned. Biopsies were taken from the daughter on three occasions as an inpatient under normal and restricted dietary regimens. Tissue for comparison was obtained by a similar needle biopsy technique from a further seven obese patients (mean weight $102(62-170) \mathrm{kg}$, mean height $142 \mathrm{~cm}$, mean age 48 years) after an overnight fast. Adipose tissues from all sources were immediately transferred to the laboratory in $0.9 \%$ saline for metabolic studies.

Measurement of Lipolysis.-Adipose tissue was preincubated for 30 minutes at $37^{\circ} \mathrm{C}$ in Earle's bicarbonate buffer ( $\mathrm{pH} \mathrm{7.4)}$ containing $1 \%$ bovine serum albumin (crystalline, fraction $\mathrm{V}$ ) under a gas phase of oxygen- $\mathrm{CO}_{2}$ (95:5). Pieces of tissue (about $100 \mathrm{mg}$ ) were then transferred to $0.2 \mathrm{ml}$ of fresh buffer and incubated for a further hour at $37^{\circ} \mathrm{C}$ in the presence and absence of isoprenaline $\left(10^{-5} \mathrm{M}\right)$. The tissue was then removed, blotted, and weighed. The medium was stored at $-20^{\circ} \mathrm{C}$ until required for assay of glycerol. Release of glycerol into the medium was assayed by the method of Garland and Randle (1962). Changes in optical density were recorded on a Unicam S.P. $800 \mathrm{~A}$ recording spectrophotometer fitted with a scale expansion accessory. Standard curves were linear over a range of $0-20$ nM glycerol.

Measurement of Cyclic-AMP.-Adipose tissue was preincubated for 30 minutes in Earle's bicarbonate buffer ( $\mathrm{pH} 7 \cdot 4$ ) with theophylline $(10 \mathrm{mM})$ to inhibit the phosphodiesterase. Tissue pieces (about $50 \mathrm{mg}$ ) were then transferred to fresh buffer and incubated for five minutes with or without isoprenaline $\left(10^{-5} \mathrm{M}\right)$. The tissue was then removed quickly and placed in ice-cold $6 \% \mathrm{HCl}(0.2 \mathrm{ml})$ and, after weighing, was homogenized with a motor-driven Teflon pestle. The fat was extracted with ether and the aqueous extract was neutralized with $50 \mu \mathrm{l}$ of potassium hydroxide and any residual ether removed in a stream of air. The extracts were stored at $-20^{\circ} \mathrm{C}$ until required for assay. 
Cyclic-AMP was measured using the method of Brown et al. (1971). The binding protein was extracted from beef adrenal cortex, and standard curves were linear over $0.5-20$ pmol of cyclic-AMP. Treatment of tissue extracts with phosphodiesterase abolished the displacement of standard tritiated cyclicAMP from binding to adrenal protein.

\section{Results}

A dose-response curve for the stimulation of tissue levels of cyclic-AMP and release of glycerol from adipose tissue by isoprenaline is shown in the fig. A maximal response for both criteria was achieved at doses of $10^{-6}$ to $10^{-5} \mathrm{M}$, and the latter was the usual concentration of isoprenaline used since the variability seemed to be less at this level. The effects of isoprenaline on levels of cyclic-AMP and release of glycerol from adipose tissue of the patients under study and of a group of seven obese controls are shown in the table. In all subjects a greater than five-fold increment was observed in tissue levels of cyclicAMP on incubation with isoprenaline $\left(10^{-8} \mathrm{M}\right)$; and the mean increments are not statistically different between the three groups.
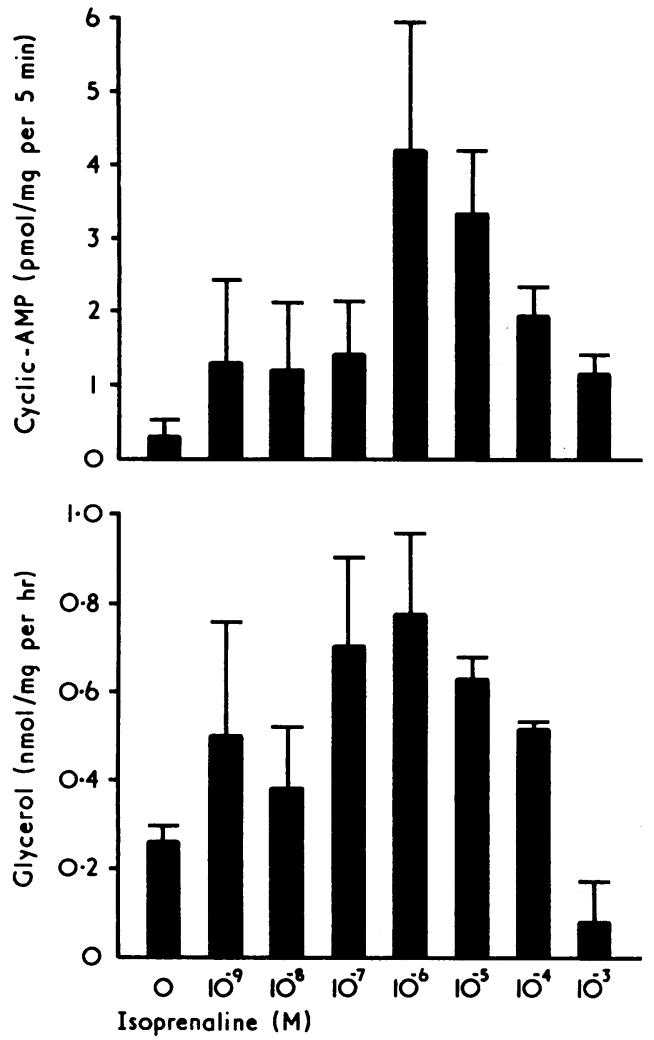

The effect of isoprenaline on levels of cyclic-AMP and release of glycerol from human adipose tissue. Bars are means \pm S.E. of mean of three patients for release of glycerol and four patients for assays of cyclic-AMP.

Effect of Isoprenaline $\left(10^{5} M\right)$ on Adipose Tissue in Obesity. Results are Means \pm S.E. of mean (No. of observations) of the Basal Values and Increments Above Basal Values Due to Isoprenaline.

\begin{tabular}{|c|c|c|c|c|}
\hline \multirow{2}{*}{$\begin{array}{l}\text { Subiects } \\
\text { Studied }\end{array}$} & \multicolumn{2}{|c|}{$\begin{array}{c}\text { Levels of Cyclic-AMP } \\
\text { (pmol/mg/5 min) }\end{array}$} & \multicolumn{2}{|c|}{$\begin{array}{l}\text { Release of Glycerol } \\
\mathrm{nmol} / \mathrm{mg} / \mathrm{hr})\end{array}$} \\
\hline & Basal & Increment & Basal & Increment \\
\hline $\begin{array}{l}\text { Mother } \quad . \\
\text { Daughter } \\
\text { Obese controls }\end{array}$ & $\begin{array}{l}0.42 \pm 0.14 \text { (7) } \\
0.19 \pm 0.09 \text { (8) } \\
0.64 \pm 0.37 \text { (7) }\end{array}$ & $\begin{array}{l}2.19 \pm 0.45(7) \\
1.80 \pm 0.30(8) \\
3.5 \pm 1.06(7)\end{array}$ & $\begin{array}{l}0.096 \pm 0.029(6) \\
0.128 \pm 0.001(3) \\
0.10 \pm 0.036(7)\end{array}$ & $\begin{array}{l}0.06 * \pm 0.02(6) \\
0.111 \pm 0.05 \text { (3) } \\
0.247 * \pm 0.07 \text { (7) }\end{array}$ \\
\hline
\end{tabular}

Significance of differences were calculated by Student's $t$ test $(P<0.05)$. Tissue (50-100 mg) was incubated with or without isoprenaline $\left(10^{-6} \mathrm{M}\right)$ and the rise in
The corresponding release of glycerol in the mother was reduced compared to obese controls $(P<0.05)$ and the glycerol release above her basal values was not statistically significant. In the daughter the incremental release of glycerol was diminished compared to obese controls and in both patients the incremental release of glycerol stimulated by isoprenaline was less than the basal release. A further obese patient with ischaemic heart disease who had a type IIb hyperlipaemia similar to the mother showed a normal increment of cyclic-AMP (3.41 \pm 1.2 $\mathrm{pmol} / \mathrm{mg} / 5 \mathrm{~min}$ on four observations) and a normal increment of glycerol $(0.185 \mathrm{nmol} / \mathrm{mg} / \mathrm{hr}$ on two occasions) when stimulated by isoprenaline.

Although the lipolytic response of adipose tissue to isoprenaline was impaired in the mother, it is possible that other lipolytic stimuli may be effective. She was therefore fasted for a period of 14 days, during which time she lost $5.3 \mathrm{~kg}$ in weight. Over this period her plasma fatty acids were $0.4,0.5,1.0,1.4$, and $1.2 \mathrm{mM}$ at days $0,5,7,9$, and 14 from the start of the fast. Likewise, the daughter was fasted for three days, and her plasma fatty acids rose $0.3,0.6,0.65$, and $0.8 \mathrm{mM}$ on days $0,1,2$, and 3 from the start of the fast.

\section{Discussion}

The mother showed a persistent defect in lipolysis of her subcutaneous adipose tissue after stimulation by isoprenaline in vitro ( $P<0.05$ compared to obese controls). This was assessed by release of glycerol from the tissue since the release of fatty acids can be increased not only by accelerating lipolysis but also by reducing re-esterification of fatty acids to triglyceride. Despite this failure to stimulate release of glycerol on incubation with isoprenaline, adipose tissue from the mother responded normally by a rise in tissue levels of cyclic-AMP. This suggests that the lipolytic defect of (D.D.) is at a later stage than adenyl cyclase and cyclic-AMP. However, lipolysis in this patient was stimulated by a 14-day fast as judged by the rise in plasma levels of free fatty acids-although this in part may be due to decreased re-esterification of fatty acids in adipose tissue. The rise in plasma fatty acids may mean that either the lipolytic defect in this patient is not present at all other sites, such as mesenteric, pelvic, and thoracic adipose tissue, or that the triglyceride-lipase is normal in her case but is activated in the fasting state by a mechanism not involving cyclic-AMP. There is evidence that the acceleration of lipolysis during a fast does not depend on increased formation of cyclic-AMP, but may perhaps be due to enzyme induction of new triglyceride-lipase (Fain, 1967), with the proportion of active to inactive enzyme remaining the same.

The sequence of events by which catecholamines stimulate lipolysis in adipose tissue is thought to involve the following: accelerated formation of cyclic-AMP by adenyl cyclase; cyclicAMP activates a protein kinase; the latter in its turn activating a triglyceride-lipase, which is the rate-determining step in lipolysis and therefore regulates the overall pathway (Huttenen et al., 1970). The fact that adipose tissue from the mother responded to isoprenaline by a rise in tissue levels of cyclic-AMP with an impaired release of glycerol, and on fasting produced a normal rise in plasma fatty acids, therefore points to a defect in the lipolytic sequence at the level of the protein kinase, or to a defect in the diglyceride or monoglyceride lipase.

In this connexion it is of interest that the reactions regulating triglyceride breakdown in adipose tissue are closely analogous to the reactions regulating glycogen breakdown in liver. Both involve adenyl cyclase, cyclic-AMP, phosphodiesterase, and protein kinases. Of the nine types of glycogen storage disease already described, types VIII and IX are due to defects in the protein kinase activation of the phosphorylase system in liver.

Hug et al. (1970) reported on a patient who appeared to have a defect of the protein kinase involved in phosphorylase activation with a consequent accumulation of glycogen in liver and muscle. Homogenates of her muscle lacked a cyclic-AMP-dependent kinase and were unable to activate her own or rabbit muscle 
phosphorylase b, except at a tenth of the normal rate. Activation of phosphorylase $b$, however, was restored to normal by addition of mouse muscle homogenates containing protein kinase but deficient in phosphorylase kinase. This therefore suggests a reduction in protein kinase activity in this patient's muscles. Similarly in the mother in the present study the defect involved in triglyceride breakdown in adipose tissue may possibly be located at the protein kinase involved in the activation of triglyceride lipase. This defect may be on a familial basis since her obese daughter with a hyperlipaemia also showed a reduction in glycerol release from her adipose tissue on stimulation with isoprenaline, despite normal rises in tissue levels of cyclic-AMP. Further work is being conducted to clarify the exact nature of the defects in mobilization of triglycerides from adipose tissue in these two patients. It should be finally emphasized that this defect is likely to be of rare occurrence and is therefore likely not to be an aetiological factor in most overweight patients.
This work was supported by grants from the Servier Laboratories and the Joint Research Board of St. Bartholomew's Hospital, for which the authors are particularly grateful.

\section{References}

Bjorntorp, P., and Hood, B. (1966). Acta Medica Scandinavica, 179, 221 Brown, B. L., Albano, J. D. M., Ekins, R. P., and Sgherzi, A. M. (1971).

Fain, J. N. (1967). Advances in Enzyme Regulation, 5, 39.

Galton, D. J., and Bray, G. A. (1966). Fournal of Clinical Investigation, 45, 1010.

Garland, P. B., and Randle, P. J. (1962). Nature, 196, 987.

Glennon, J. A., Brech, W. J., and Gordon, E. S. (1964). Clinical Research, $14,348$.

Hug, G., Schubert, W. K., and Chuck, G. (1970). Biochemical and Biophysical Research Communications, 40,982

Huttenen, J. K., Ellingboe, J., Pittman, R. C., and Steinberg, D. (1970) Biochemical and Biophysical Acta, 218, 333 .

Orth, R. D., and Williams, R. H. (1960). Proceedings of the Society for Experimental Biology and Medicine, 104, 119.

\section{MEDICAL MEMORANDA}

\section{Stilboestrol Diphosphate in Hypercalcaemia due to Parathyroid Carcinoma}

\author{
G. SIGURDSSON, N. J. Y. WOODHOUSE, \\ SELWYN TAYLOR, G. F. JOPLIN
}

British Medical fournal, 1973, 1, 27-28

Parathyroid carcinoma is a rare cause of primary hyperparathyroidism. Complete surgical excision of the tumour is of ten difficult and local recurrence is common; metastases may occur many years later. These tumours are usually resistant to radiotherapy. Medical management of the hypercalcaemia is also difficult and the patient usually dies of hypercalcaemic crisis or of renal failure.

In the case described here severe hypercalcaemia was not controlled by phosphate, synthetic human calcitonin, mithramycin, glucagon, or multiple cytotoxic therapy but responded to stilboestrol diphosphate.

\section{Case Report}

A man aged 53 presented in 1968 with pathological fractures and widespread bone pain. His serum calcium was $8.5 \mathrm{mEq} / 1$. and alkaline phosphatase 60 K.A. units. Radiographs showed osteitis fibrosa cystica. In December 1968 a parathyroid tumour, which was adherent to the oesophagus, was removed. It weighed $5 \mathrm{~g}$ and its histology was that of a parathyroid carcinoma invading surrounding tissue. The patient's serum calcium reverted to normal and he remained in good health until early in 1971, when bone pains recurred associated with thirst, polyuria, and nausea.

He was referred to us in Cctober 1971, when he looked ill,

\footnotetext{
Departments of Medicine and Surgery, Royal Postgraduate Medical School, London W12 OHS

G. SIGURDSSON, CAND. MED., Research Fellow

N. J. Y. WOODHOUSE, M.R.C.P., Research Fellow and Honorary Senior Registrar

G. F. JOPLIN, PH.D., F.R.C.P., Consultant Physician
}

complained of generalized bone pains, and had bone tenderness. Investigations were: serum calcium $8.5 \mathrm{mEq} / 1$., inorganic phosphate $1.8 \mathrm{mEq} / 1$, alkaline phosphatase $85 \mathrm{~K}$.A. units mainly of bony type (normal < 13), total acid phosphatase 8.5 K.A. units (normal $<3.5$ ), tartrate labile fraction 0.6 K.A. units (normal $<0.8$ ), urine calcium $45 \mathrm{mEq} / 24 \mathrm{hr}$ on a daily calcium intake of less than $10 \mathrm{mEq}$, and blood urea $55 \mathrm{mg} / 100 \mathrm{ml}$. The phosphate excretion index was +0.5 (normal \pm 0.09 ) (Nordin and Fraser, 1960). Calcium absorption measured by a double isotope technique was $43 \%$ (normal 30-63\%) (Reiner et al., 1970). $X$-ray examination showed widespread and florid osteitis fibrosa cystica. A very high bone turnover was shown by a 24 -hour calcium-47 space of 54 plasma units (normal $<18$ ) and a mean total urine hydroxyproline of $570 \mathrm{mg} /$ day (range $344-708 \mathrm{mg} /$ day) (normal $<50 \mathrm{mg}$ ). A biopsy from a bone cyst in the left pubic bone showed osteitis fibrosa but no malignant cells were seen.

In October 1971 the patient's neck was re-explored by S.T. and the sternum split. Three normal parathyroid glands were found but no tumour tissue. There was no postoperative fall in serum calcium. Palliation of the hypercalcaemia was attempted with a low calcium diet, a high fluid intake, and various more specific treatments. Intramuscular injections of synthetic human calcitonin $0.5 \mathrm{mg}$ three times a day caused a fall in serum calcium towards normal, but it was not sustained for more than 48 hours despite continuous administration for six days and a supplementary infusion of $10 \mathrm{mg}$ over 24 hours. Elemental phosphorus, $2 \mathrm{~g}$ daily by mouth, had little or no effect on the serum calcium while intravenous infusions of $1 \mathrm{~g}$ of phosphorous element and mithramycin infusions of $2 \mathrm{mg}$ caused only shortlived falls. A single administration of combined cytotoxics consisting of cyclophosphamide $(1,000 \mathrm{mg})$, fluorouracil $(750 \mathrm{mg})$, actinomycin D $(0.5 \mathrm{mg})$, vincristine $(2 \mathrm{mg})$, methotrexate $(200 \mathrm{mg})$, and mithramycin ( $2 \mathrm{mg}$ ) had a shortlived effect similar to that of mithramycin alone. Intramuscular injections of glucagon, $1 \mathrm{mg}$ twice daily for 15 days, did not alter the serum calcium. Venous catheterization of the neck and inferior vena cava was done, and the highest values of parathyroid hormone measured by immunoradiometric assay were found in the right innominate vein at the base of the neck $(9.3 \mathrm{ng} / \mathrm{ml})$.

The patient's neck was re-explored on 14 December, but no tumour tissue was found. There was no fall in serum calcium, the patient remained critically ill, suffering intensely from generalized bone pains.

\section{STILBOESTROL DIPHOSPHATE THERAPY}

Starting on 21 December, daily injections of stilboestrol diphosphate $1,000 \mathrm{mg}$ were given intravenously for four days. During the first intravenous injection the patient felt extreme and general- 